\title{
Modeling for determining the superiority of Holstein bulls as frozen semen producer and genetic source for milk production
}

\author{
A. Argiris, S. I. Santoso, Y. S. Ondho and E. Kurnianto* \\ Faculty of Animal and Agricultural Sciences, Diponegoro University, \\ Tembalang Campus, Semarang 50275 - Indonesia. \\ *Corresponding E-mail: kurniantoedy17@gmail.com
}

Received October 17, 2018; Accepted December 04, 2018

\begin{abstract}
ABSTRAK
Tujuan penelitian ini adalah untuk menyusun model dalam memperoleh nilai keunggulan pejantan Holstein sebagai penghasil semen beku dan sumber genetis produksi susu sapi perah. Kemampuan pejantan untuk menghasilkan semen beku per tahun dianalisis secara deskriptif. Nilai efisiensi reproduksi semen beku dalam inseminasi buatan dihitung dengan service per conception (S/C). Estimasi nilai pemuliaan pejantan untuk produksi susu dievaluasi melalui metode contemporary comparison (CC). Model nilai keunggulan pejantan dianalisis menggunakan Structural Equation Model-Partial Least Square (SEM-PLS). Rata-rata produksi semen beku per pejantan adalah $23.109 \pm 14.970$ dosis/tahun. Nilai rata-rata $\mathrm{S} / \mathrm{C}$ adalah 2,83 . Nilai CC antara $-1.865,7$ sampai $+1.636,3$. Potensi produksi susu yang dihasilkan dari betina laktasi keturunan per pejantan yang diuji antara 951.749,2 sampai 52.347.822,9 liter per tahun. Nilai ekonomis pejantan berdasarkan potensi produksi susu betina antara Rp. 4.758.745.999. sampai Rp. 261.739.114.505. Nilai keunggulan pejantan dipengaruhi $(\mathrm{P}<0,05)$ oleh koefisien kemampuan pejantan untuk menghasilkan semen beku sebesar 0,59; efisiensi reproduksi sebesar $-0,53$ dan rata-rata produksi susu anak betinanya sebesar 0,33 . Kesimpulan penelitian ini adalah nilai keunggulan pejantan dapat dijelaskan sebesar 78,3\% oleh nilai kemampuan pejantan untuk menghasilkan semen beku, efisiensi reproduksi dan produksi susu anaknya.
\end{abstract}

Kata kunci: produksi semen beku, efisiensi reproduksi, nilai pemuliaan, keunggulan pejantan

\section{ABSTRACT}

The objective of this study was to develop models for determination the superiority of Holstein bulls as a producer of frozen semen and inheritance of the genetic traits of milk production. The ability of the bull to produce frozen semen per years was analyzed descriptively. Reproductive efficiency of frozen semen in artificial insemination was calculated by service per conception $(\mathrm{S} / \mathrm{C})$. Estimation sire breeding value for milk production was calculated by contemporary comparison (CC) method. Model of superiority bulls was analyzed by Structural Equation Model with Partial Least Square method (SEMPLS). Total average production of frozen semen was $23,109 \pm 14,970$ doses/year. The average S/C was 2.83. The $\mathrm{CC}$ value ranged from $-1,865.7$ until $+1,636.3$. Potency of milk production resulted from lactation cow offspring per bulls ranged from 951,749.2 to 52,347,822.9 liters per year. The economic value of bulls based on the potency milk production of offspring ranges from IDR 4,758,745,999 to IDR $261,739,114,505$. The superiority of bulls was affected significantly $(\mathrm{P}<0.05)$ by frozen semen production, reproductive efficiency and average milk production of daughter cows (DC) as much as $0.59,-0.53$ and 0.33 , respectively. In conclusion, the superiority of bull can be explained about $78.3 \%$ by the production of frozen semen production, reproductive efficiency and milk production of offspring.

Keywords: frozen semen production, reproductive efficiency, breeding value, superiority of bull 


\section{INTRODUCTION}

The superiority of Holstein bulls in terms of economic traits are the ability of bull to produce frozen semen, reproductive efficiency and genetic traits of milk production measured simultaneously. This statement was in accordance with Fuerst-Waltl et al. (2016) who stated that economical traits should be considered in the breeding objective, included production and functional traits in order to get qualified bull.

Study on the superiority of bulls have been conducted separately based on economic traits like bull breeding soundness evaluation (BBSE) and semen quality (Purwantara et al., 2010; Chenoweth and McPherson, 2016; PenitenteFilho et al., 2018); reproductive efficiency (Pecsok et al., 1994; Plaizier et al., 1996; Fernando et al., 2016); breeding value (Wilder and Van Vleck, 1988; Groen and Steine, 1997; ElBayoumi et al., 2015). Chenoweth and McPherson (2016) stated that bull breeding soundness evaluation (BBSE) is able to describe the superiority of bulls based on their ability to produce frozen semen by $65-85 \%$. Quality semen is one of four factors $(25 \%)$ affecting successful service of insemination such as skill of inseminator, timing of insemination and status reproduction cows (Fernando et al., 2016). Heritability of milk production was medium, being $0.34 \pm 0.02$ (scale $0-1$ ), so that it has little effect on the measurement of bull superiority (ElBayoumi et al., 2015). The problem is if the evaluation of superiority bull was limited on one trait separately, then it would unable to describe and measure interactions among traits and would have an impact in the mistaken decision in the bull selection. To obtain more accurate overview, it was important to evaluate the economic traits affecting the bull superiority thoroughly and simultaneously by using more comprehensive model. The objective of this study was to develop model for determination the superiority of Holstein's bull as a producer of frozen semen and inheritance of the genetic traits of milk production.

\section{MATERIALS AND METHODS}

\section{The Ability of the Holstein Bull to Produce Frozen Semen}

The study was conducted at Lembang and Singosari Artificial Insemination Center (AIC),
Indonesia. Data used in this study were 24,634 data of frozen semen production from 67 Holsteins bulls (2-9 years old) as producer of frozen semen during the production period from 2008 to 2016. Data were analyzed descriptively.

\section{Determination of Reproductive Efficiency of Frozen Semen of Holstein Bull in AI Activities}

Reproductive efficiency of frozen semen in artificial insemination (AI) was used service per conception (S/C) value calculated from reproduction record of AI acceptor at the dairy farmer located in Java Island that used frozen semen produced by Lembang and Singosari AIC. The Java Island was selected as the location of the study based on a report of Anggraeni (2012) which stated that the Java Island has $97.2 \%$ of the Holstein population $\mathrm{s}$ in Indonesia. The $\mathrm{S} / \mathrm{C}$ was calculated by formula of Atabany et al. (2011).

Prediction numbers potential calving of lactation cows was calculated using frozen semen production (dose/year), S/C and reproductive technique coefficient on dairy cows according to Sadeghi et al. (2012) including embryo mortality $(5 \%)$; calf mortality $(10 \%)$; sex ratio (1:1) cow mortality $(8 \%)$ and percentage of lactation cow $(80 \%)$.

\section{Determination of Genetic Superiority}

The observed data were milk production record of daughter cows (DC) of Lembang and Singosari bulls and milk production records of contemporary cows at the same location and age at period 2011-2017. The full milk production per lactation was estimated using test-day method, standardized to 305 days milk production, milking twice daily and mature age based on DHIAUSDA correction factors (Hardjosubroto, 1994). Estimation of sire breeding value for milk production was calculated by Contemporary Comparison (CC) method described by Kurnianto (2012) which fit to smallholder farmer with ownership of less than 5 cows. The formula of CC was:

Where:

$$
\begin{gathered}
\mathrm{CC}=\frac{\sum\left[\mathrm{W}_{\mathrm{i}}\left(\overline{\mathrm{Y}}_{1}-\overline{\mathrm{Y}}_{\mathrm{c}}\right)\right]}{\sum \mathrm{W}_{\mathrm{i}}} \\
\mathrm{W}_{\mathrm{i}}=\frac{\mathrm{n}_{1} \times \mathrm{n}_{2}}{\mathrm{n}_{1}+\mathrm{n}_{2}}
\end{gathered}
$$

$\mathrm{CC}=\mathrm{CC}$ value

$\mathrm{W}_{\mathrm{i}}$ : Weighted factor 
$\mathrm{n}_{1}$ : Number of daughter cows

$\mathrm{n}_{2}$ : Numbers of contemporary

$\overline{\mathrm{Y}}_{\mathrm{i}}$ : Milk production average of daugter

$\bar{Y}_{c}$ : Milk production average of contemporary

The potency of milk production per bulls was calculated based on the potency of the number of the lactation DC multiplied by average of milk production from DC of bull's offspring tested. The economic value of bull was calculated based on milk price assumption of IDR $5,000 /$ liter.

\section{Statistical Methods}

Effect of age and bulls in frozen semen production were analyzed by nested design. Statistical model was:

$$
\begin{aligned}
& Y_{i j k}=\mu+A_{i}+B_{j(i)}+\varepsilon_{(i j) k} \\
& i=1,2,3, . ., a \\
& j=1,2,3, . . b \\
& k=1,2,3, . . c
\end{aligned}
$$

\section{Where}

$\mathrm{Y}_{\mathrm{ijkl}}$ : The $\mathrm{k}^{\text {th }}$ observation, the $\mathrm{j}^{\text {th }}$ age factor and the $\mathrm{i}^{\text {th }}$ bull factor

$\mu \quad$ : Overall mean

$\mathrm{A}_{\mathrm{i}} \quad$ : Effect of $i^{\text {th }}$ bull

$B_{j(i)}:$ Effect of $j^{\text {th }}$ age factor of $i^{\text {th }}$ bull

$\varepsilon_{(\mathrm{ij}) \mathrm{k}}$ : Effect of error

The model of superiority bulls was analyzed by SEM-PLS 3.0. According to Sholihin and Ratmono (2013), partial least square (PLS) was a variance-based structural equation analysis (SEM) that can simultaneously perform testing of measurement models as well as structural model testing. SEM-PLS can estimate $p$ values for path coefficients and can provide an indicator criteria of fit model in the form of average R-squared (ARS), average path coefficient (APC) and average variance inflation factor (AVIF). The statistical model is:

$$
Y=\beta_{1} X_{i}+\beta_{2} X_{2}+\beta_{3} X_{3}+\varepsilon
$$

\section{Where}

$$
\begin{aligned}
& \mathrm{Y} \quad \text { : } \begin{array}{l}
\text { Superiority bulls based on the potential } \\
\text { of milk production }
\end{array} \\
& \beta_{1} \quad: \text { The coefficient value of frozen semen } \\
& \text { production path }
\end{aligned}
$$

$\beta_{2}$ : The coefficient value of the reproductive efficiency path

$\beta_{3}$ : The coefficient value of milk production path

$\mathrm{X}_{1} \quad$ : Average production of frozen semen per bulls

$\mathrm{X}_{2}$ : Average reproductive efficiency per bulls $(\mathrm{S} / \mathrm{C})$

$\mathrm{X}_{3}$ : Average milk production of daughter cows per bulls

$\varepsilon \quad$ : Error

\section{RESULTS AND DISCUSSIONS}

\section{Ability of the Holstein Bull to Produce Frozen Semen}

The average total production of frozen semen per bull per years is presented in Table 1. The total production of frozen semen per bull ranged from $1,270 \pm 1,124$ until $70,577 \pm 2,492$ doses/year. Total average production of frozen semen was 23,109 $\pm 14,970$ doses/year. The production of frozen semen per year was varying greatly due to the bull's condition, the frequency of semen collection, the quality of fresh semen and the frozen semen processing. The average production of frozen semen per year is lower than that reported by Tiwari et al. (2012) amounting to 39,536 doses/year on Sahiwal bulls but higher than the report of Bhosrekar et al. (1980) 10,458 doses/year of Holstein bulls in Sri Lanka. This low amount of frozen semen production was caused by poor health conditions of bulls, which affected the frequency of collection and quality of semen produced. The high variation coefficient showed that the average production of frozen semen per year was influenced by the age of bull $(\mathrm{P}<0.01)$. It is in accordance with Fuerst-Waltl et al. (2016) which stated that the age had a significant influence on semen traits of semen Simmental bulls in Austria.

\section{Determination of reproductive efficiency of frozen semen of Holstein bulls in AI activities}

Qualified frozen semen improves the reproductive efficiency of AI activities. The reproductive efficiency data per bulls is presented in Table 2. The reproduction data records in this study were 100,564 acceptors with the use of frozen semen as many as 149,215 doses from 52 Holsteins bull. Numbers of pregnancies were $59.67 \%$ indicating that the pregnancy rate was 
Table 1. The Average Production of Frozen Semen per Bull per Years

\begin{tabular}{clcc}
\hline No & Bull Name & Frozen Semen (dose) & Coefficient of Variation (\%) \\
\hline 1 & Maxwell & $1,270 \pm 1,124$ & 88.53 \\
2 & Fluto & $2,581 \pm 2,306$ & 89.36 \\
3 & Jaysy & $2,933 \pm 1,232$ & 41.98 \\
4 & Fortuner & $3,842 \pm 3,179$ & 82.74 \\
5 & Florean & $3,899 \pm 2,128$ & 54.57 \\
& $\ldots \ldots$ & $\ldots \ldots$ & $\ldots \ldots$ \\
& $\ldots \ldots$ & $\ldots \ldots$ & $\ldots \ldots$ \\
61 & $\ldots \ldots$ & $\ldots \ldots$ & $\ldots \ldots$ \\
62 & $\ldots \ldots$ & $46,828 \pm 26,545$ & 56.69 \\
63 & Pland & $47,268 \pm 20,086$ & 42.49 \\
64 & Astry & $53,504 \pm 32,189$ & 60.16 \\
65 & Rodgard & $56,386 \pm 27,597$ & 48.94 \\
66 & Jodan & $70,577 \pm 2,493$ & 3.53 \\
67 & Starko & $23,109 \pm 14,970$ & 64,78 \\
\hline Average & & & $\ldots .$. \\
\hline
\end{tabular}

Table 2. Reproductive Efficiency per Bull

\begin{tabular}{clrrrr}
\hline No. & \multicolumn{1}{c}{ Bull } & Acceptor & Dose & Pregnancy & S/C \\
\hline 1. & Dunde & 410 & 439 & 410 & 1.07 \\
2. & Valley & 5,880 & 8,078 & 5,875 & 1.37 \\
3. & Heroe & 171 & 244 & 166 & 1.47 \\
4. & Mohze & 3 & 3 & 2 & 1.50 \\
5. & Astry & 6,089 & 8,698 & 5,694 & 1.53 \\
$\ldots$ & $\ldots$ & $\ldots$ & $\ldots$ & $\ldots$ & $\ldots$ \\
$\ldots$ & $\ldots$ & $\ldots$ & $\ldots$ & $\ldots$ & $\ldots$ \\
48 & Bayu & 86 & 143 & 35 & 4.09 \\
49 & Tynho & 2,262 & 3,232 & 771 & 4.19 \\
50 & Sanry P & 2,320 & 343 & 771 & 4.30 \\
51 & Milky & 240 & 170 & 77 & 4.45 \\
52 & Dean & 102 & 149,215 & 60,011 & 4.59 \\
& & 100,564 & & 37 & $2.83 *$ \\
\hline
\end{tabular}

$\mathrm{S} / \mathrm{C}$ : Service per Conception, *: average

low enough from all acceptors who received AI services. The average $\mathrm{S} / \mathrm{C}$ value was 2.83 . The average $\mathrm{S} / \mathrm{C}$ value (2.83) showed there was still inefficiency reproduction performance in Indonesia. Nuryadi and Wahjuningsih (2011) reported the normal $\mathrm{S} / \mathrm{C}$ value was ranged at 1.6- 
2.0 in their study on beef cattle in Indonesia. The $\mathrm{S} / \mathrm{C}$ value (2.83) was also higher than that reported by Fernando et al. (2016) $2.1 \pm 1.29$ observe on Jersey cattle in Sri Lanka. The high $\mathrm{S} / \mathrm{C}$ in this study was considered as factor of field conditions, i.e. acceptor dispersed on small farms, farmers were late reporting estrus cattle to AI technicians resulting it too late inseminated, reproductive conditions of female cattle, and handling of frozen semen. Another reason was considering on conception of AI depends on the characteristics of the semen provided by AI centers (Ghasemi and Ghorbani, 2014).

Potential number of lactation cow per sire is presented in Table 3. The average number of lactation cows that resulted from 52 sires was 2,863 daughter cows (DC) per bull, it ranged from 296 to 12,228 daughter cows. A smaller value of $\mathrm{S} / \mathrm{C}$ and greater ability bulls to produce frozen semen affected higher potential numbers of lactation cow per bull's produced with the assumption of the other technical coefficients were constant. This is in accordance with Ferguson and Skidmore (2013) who stated that reproductive efficiency was an outcome of S/C values that can be combined with a variable determining pregnancy rate. Decreasing the number of insemination has a positive effect on the profitability and one of the most economically important traits in dairy cattle industry (Ghiasi and Honarvar, 2016; Ghiasi et al., 2016). Improvements in reproductive performance can potentially yield remarkable economic benefits (Fodor et al., 2018). Further, Villa-Arcila et al. (2018) stated that reproductive performance has also an impact on the economic results of the dairy business, as low reproductive efficiency may cause a decrease in milk production and the number of calves born per year.

\section{Determination of Genetic Superiority}

The average milk production and $\mathrm{CC}$ estimation is presented in Table 4. The numbers of milk production records that suffice the requirements for use were 1,006 records of DC milk production from 36 bulls tested and 1,019 milk production records of cows as comparative. The average population of milk production was 4,068 liters per lactation or 13.34 liters/day. The average milk production of DC from sires tested was 4,258.7 liters/lactation or 13.96 liters/day with a ranged from 2,320.1 to 7,128.6 liters/lactation. The $\mathrm{CC}$ value ranged from $-1,865.7$ to $+1,636.3$; these showed that the lowest average milk production per lactation was $1,865.7$ liters below the average milk production of

Table 3. Potential Number of Lactation Cow per Sire

\begin{tabular}{rlrrrrrrrrr}
\hline No & Bull & $\begin{array}{c}\text { Frozen } \\
\text { Semen/ } \\
\text { years }\end{array}$ & S/C & Pregnancy Embryo & Calf $^{2}$ & Male $^{3}$ & Female $^{3}$ & Mature $^{4}$ Lactation $^{5}$ \\
\hline 1 & Dunde & 41,612 & 1.07 & 38,863 & 36,920 & 33,228 & 16,614 & 16,614 & 15,285 & 12,228 \\
2 & Astry & 47,268 & 1.53 & 30,944 & 29,396 & 26,457 & 13,228 & 13,228 & 12,170 & 9,736 \\
3 & Rodgard & 53,504 & 2.56 & 20,870 & 19,826 & 17,844 & 8,922 & 8,922 & 8,208 & 6,566 \\
4 & Mohze & 30,116 & 1.50 & 20,077 & 19,073 & 17,166 & 8,583 & 8,583 & 7,896 & 6,317 \\
5 & Sg Casir & 44,315 & 2.22 & 19,993 & 18,993 & 17,094 & 8,547 & 8,547 & 7,863 & 6,291 \\
& $\ldots$ & $\ldots$ & $\ldots$ & $\ldots$ & $\ldots$ & $\ldots$ & $\ldots$ & $\ldots$ & $\ldots$ & $\ldots$ \\
& $\ldots$ & $\ldots$ & $\ldots$ & $\ldots$ & $\ldots$ & $\ldots$ & $\ldots$ & $\ldots$ & $\ldots$ & $\ldots$ \\
48 & Franko & 3,410 & 2.17 & 1,569 & 1,490 & 1,341 & 671 & 671 & 617 & 494 \\
49 & Heroe & 2,290 & 1.47 & 1,558 & 1,480 & 1,332 & 666 & 666 & 613 & 490 \\
50 & Fortuner & 3,842 & 2.52 & 1,525 & 1,449 & 1,304 & 652 & 652 & 600 & 480 \\
51 & Florean & 3,899 & 3.00 & 1,302 & 1,237 & 1,113 & 556 & 556 & 512 & 410 \\
52 & Milky & 4,187 & 4.45 & 940 & 893 & 804 & 402 & 402 & 370 & 296 \\
\hline
\end{tabular}

1. Embryo mortality: 5\%; 2. Calf mortality: $10 \%$; 3. Sex ratio:50:50; 4. Mature mortality : 8\%; 5 . Lactation mortality: $20 \%$. 
Table 4. Average Milk Production and Contemporary Comparison of Holstein Bull

\begin{tabular}{|c|c|c|c|c|c|c|c|c|}
\hline \multirow{2}{*}{ No } & \multirow{2}{*}{ Bull } & \multicolumn{2}{|c|}{ Number of } & \multirow{2}{*}{$\mathrm{DC}$} & \multirow{2}{*}{$\mathrm{PC}$} & \multirow{2}{*}{ W } & \multirow{2}{*}{$\mathrm{CC}$} & \multirow{2}{*}{ EBV } \\
\hline & & $\mathrm{n}_{1}$ & $\mathrm{n}_{2}$ & & & & & \\
\hline 1 & Black & 3 & 7 & 5929.2 & 5491.2 & 2.1 & 1636.3 & 3272.5 \\
\hline 2 & Florean & 25 & 187 & 5607.5 & 4506.2 & 17.5 & 909.8 & 1819.5 \\
\hline 3 & Flaunt & 21 & 238 & 5369.4 & 4465.5 & 16.9 & 839.6 & 1679.3 \\
\hline 4 & Hostormsy & 28 & 320 & 4041.8 & 3688.9 & 23.1 & 778.5 & 1557.0 \\
\hline 5 & Fokker & 17 & 165 & 5179.4 & 4505.8 & 13.2 & 777.9 & 1555.7 \\
\hline.. & $\ldots$ & $\ldots$ & $\ldots$ & $\ldots$ & $\ldots$ & $\ldots$ & $\ldots$ & $\ldots$ \\
\hline.. & $\cdots$ & $\ldots$ & $\cdots$ & $\ldots$ & $\ldots$ & $\ldots$ & $\ldots$ & $\ldots$ \\
\hline.. & $\ldots$ & $\ldots$ & $\ldots$ & $\ldots$ & $\ldots$ & $\ldots$ & $\ldots$ & $\ldots$ \\
\hline 32 & Anata & 5 & 26 & 2954.7 & 3593.3 & 4.1 & -745.0 & -1490.0 \\
\hline 33 & Danilsy & 19 & 131 & 3404.1 & 4961.5 & 15.6 & -826.7 & -1653.4 \\
\hline 34 & Aryana & 50 & 107 & 2506.2 & 3996.2 & 23.9 & -1276.1 & -2552.1 \\
\hline 35 & Bayu & 3 & 69 & 2320.1 & 3804.5 & 2.8 & -1411.6 & -2823.2 \\
\hline 36 & Dundee & 5 & 17 & 4281.0 & 6146.7 & 3.9 & -1865.7 & -3731.5 \\
\hline
\end{tabular}

*) = number of offspring at different farm and time; $\mathrm{n}_{1}=$ number of daughter $; \mathrm{DC}=$ daughter cow milk production $\mathrm{PC}=$ contemporary milk; $\mathrm{CC}=$ comtemporary comparison $\mathrm{EBV}=$ estimated breeding

population tested while the highest production was 1,636.3 liters above the population. The number of bulls with a positive CC score was 20 bulls or $56 \%$ of the total bulls tested and recommended as the bulls donors for the genetic traits of milk production. The difference in $\mathrm{CC}$ value was influenced by the average production and the number of DC per sire. The different amount of DC was caused by poor awareness of farmers to record milk production, so it was difficult to obtain a lot of milk production data. Milk production can be increased through genetic and environmental factors. Efforts to increased milk production could be achieved by selecting bulls whose have positive CC values. Identification sire with high genetic potential is a challenge for animal breeding (Rotar et al., 2016). Genetic improvement is one of the main factors responsible for the large increase in milk yield of dairy cow; this success is mainly attributable to the efficient application of AI with semen from proven sire was selected by progeny test (Yang et al., 2018).

The potency of milk production and economic value per bull is presented in Table 5 . The potency of milk production resulted from lactation cow offspring per bulls ranged from
$951,749.2$ to $52,347,822.9$ liter/years. The economic value of bulls based on the potency milk production of offspring ranges from IDR $4,758,745,999$ to IDR $261,739,114,505$. The greater potential for milk production and economic value of the bulls tested will be obtained if the ability of bulls to produce frozen semen was high, the S/C value was low and the milk production of DC was high. The result discussion confirmed the statement of DeJarnette et al. (2004) who stated that the AI industry must supply the genetic resources for the dairy industry's with specific breeding objectives; including the emphasis placed on production, type and reproduction in AI sire programs which largely directed to dairy producers through their semen purchasing options.

\section{Model of superiority bulls}

The model obtained was declared fit based on the value of average path coefficient (APC), average R-squared (ARS) and average variance inflation factor (AVIF) were 0.481, 0.783, 1.225, which fit the requirements according to Sholihin and Ratmono (2013), being less than 0.05 $(\mathrm{P}<0.001), 0.05 \quad(\mathrm{P}<0.001), 5$, respectively. The ARS value showed the variance of the superiority 
of bull can be explained $78.3 \%$ by the production of frozen semen production, reproductive efficiency and milk production of offspring factors and the rest $(21.7 \%)$ determined by other factors that were not measured.

Structural equation model of superiority bulls is presented in Figure 1. The superiority of bulls was affected significantly $(\mathrm{P}<0.05)$ by coefficient of frozen semen production, reproductive efficiency and average milk production of DC which found $0.59,-0.53$ and 0.33 , respectively. The model equation obtained was $\mathrm{Y}=0.59 \mathrm{X}_{\mathrm{i}}-0.53 \mathrm{X}_{2}+0.33 \mathrm{X}_{3}+\varepsilon$. These path coefficients values showed the ability of bulls to produce frozen semen (0.59) and the reproductive efficiency $(-0.53)$ have more considerable value than the genetic potential of milk production $(0.33)$. Therefore, the ability of Holstein bulls to produce qualified frozen semen maximally in an effort to increase reproductive efficiency in AI activities must take the high priority on selection bull in the AIC. This result confirmed the statement of Naha et al. (2016) that the primary goal of the AIC is to produce the

Table 5. The Potency of Milk Production and Economic Value per Bull

\begin{tabular}{clccc}
\hline No & Bull & $\begin{array}{c}\text { Number of Lactation } \\
\text { Cow (head) }\end{array}$ & $\begin{array}{c}\text { Avg. Daughter cow } \\
\text { Milk Production (Lt) }\end{array}$ & $\begin{array}{c}\left.\text { Economic Value of Bull }{ }^{*}\right) \\
(\text { IDR) }\end{array}$ \\
\hline 1 & Dunde & 12,228 & $4,281.01$ & $261,739,114,505$ \\
2 & Astry & 9,736 & $4,024.35$ & $195,907,004,018$ \\
3 & Black & 5,268 & $5,929.19$ & $156,181,714,578$ \\
4 & Prime & 4,947 & $6,007.91$ & $148,600,268,308$ \\
5 & Rodgard & 6,566 & $3,591.06$ & $117,903,206,549$ \\
$\ldots$ & & & \\
$\ldots$ & & & & \\
32 & Goldsy & 568 & $4,931.03$ & $14,013,715,041$ \\
33 & Florean & 410 & $5,607.46$ & $11,482,559,945$ \\
34 & Fortuner & 480 & $4,514.31$ & $10,828,785,510$ \\
35 & Franko & 494 & $2,642.72$ & $6,521,499,781$ \\
36 & Milky & 296 & $3,218.21$ & $4,758,745,999$ \\
\hline
\end{tabular}

*) it was assumed that the price of milk/Lt : IDR 5,000

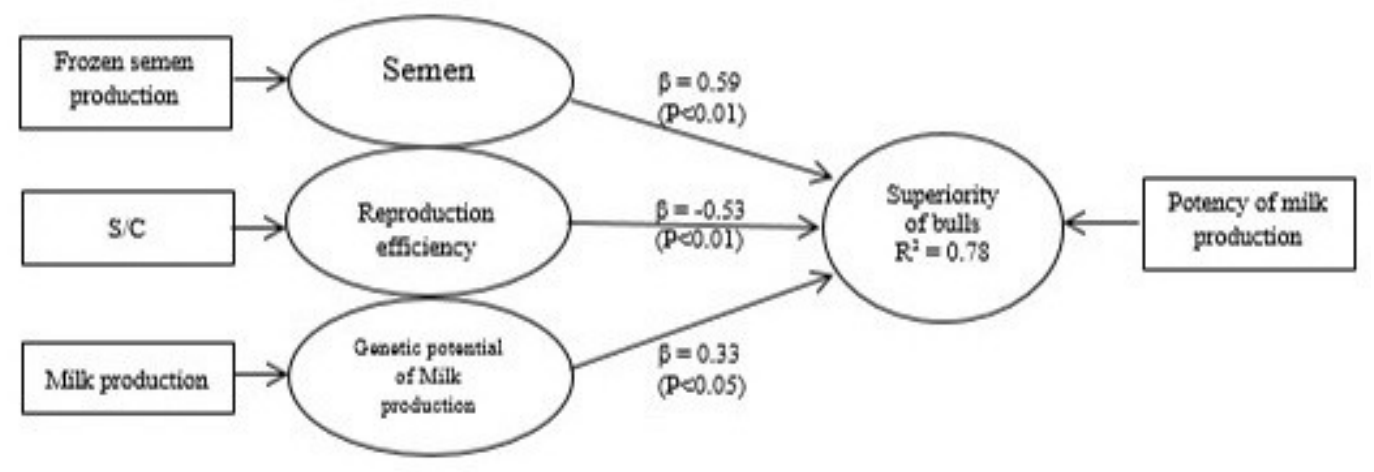

Figure 1. Structural Equation Model of Superiority Bulls 
largest quantity of the highest quality semen in a shortest possible time. The path value of genetic potential of milk production (representing heritability value) in this study was found 0.33 ; it confirmed the statement of Hardjosubroto (1994) that heritability value has a moderate criterion while environmental factors and management have a dominant influence in the milk production process of dairy cattle. Despite milk production has a moderate heritability value; the genetic trait of milk production in Holstein bull has an important role in efforts to improve the genetic quality of their offsprings. Breeders will choose the frozen semen of bull with a higher estimation breeding value (EBV) than a lower one. Kumari and Coudhary (2018) stated that detailed knowledge about raising the bulls was important for better management to support the needs of the AI industry.

\section{CONCLUSION}

Frozen semen production, reproductive efficiency and milk production of daughter cows determined the superiority of bulls. The equation of the superiority of bull $=0.59$ (semen production) -0.55 (reproductive efficiency) + 0.33 (milk production) + error. The superiority of bull could be explained about $78.3 \%$ by the production of frozen semen production, reproductive efficiency and milk production of offspring.

\section{ACKNOWLEDGMENTS}

The authors thank to Lembang and Singosari AI center; Baturraden Breeding Center of dairy cattle and Ultra Jaya Company of dairy cattle for supporting data in this study.

\section{REFERENCES}

Anggraeni, A. 2012. Perbaikan genetik sifat produksi susu dan kualitas susu sapi Friesian Holstein melalui seleksi. Wartazoa. 22(1):111.

Atabany, A., B.P. Purwanto, T. Toharmat and A. Anggraeni. 2011. Hubungan masa kosong dengan produktivitas pada sapi perah Friesian Holstein di Baturraden, Indonesia. Med. Pet. 34(2):77-82.

Bhosrekar, M.R., S.N. Sane, M.S. Sharma and
D.V. Rangnekar. 1980. Studies on the semen production of exotic bulls at the central research station of Bhartiya Agro-Industries Foundation, Urli-Kanchan. Indian J. Anim. Sci. 50(2):113-118.

Chenoweth, P.J. and F.J. McPherson. 2016. Bull breeding soundness. semen evaluation and cattle productivity. J. Anim. Reprod. Sci. 84(16):378-432.

DeJarnette, J.M., C.E. Marshall, R.W. Lenz and D.R. Monke. 2004. Sustaining the fertility of artificially inseminated dairy cattle: the role of the artificial insemination industry. J. Dairy Sci. 87(E.Suppl.):E93-E104.

El-Bayoumi, K.M., M.S. El-Tarabany, T.M. Abdel-Hamid and O.M. Mikaeil. 2015. Heritability, genetic correlation and breeding value for some productive and reproductive traits in Holstein cows. Res. Opin. Anim. Vet. Sci. 5(2):65-70.

Ferguson, J.D. and A. Skidmore. 2013. Reproductive performance in a select sample of dairy herds. J. Dairy Sci. 96(2):12701289.

Fernando, P.R.P., J. Sinniah and S. Thatchaneshkanth. 2016. Productive and reproductive performance of Jersey cattle in the Hill Country of Sri Lanka. Glob. Vet. 17(4):392-400.

Fodor, I., W. Baumgartner, Zs. Abonyi, Zs. Lang and L. Ozvari. 2018. Association between management practices and major reproductive parameters of Holstein-Friesian replacement heifers. J. Anim. Reprod. Sci. 188:114-122.

Fuerst-Waltl, B., H. Schwarzenbacher, P. Christa and J. Solkner. 2006. Effects of age and environmental factors on semen production and semen quality of Austrian Simmental bulls. J. Anim. Reprod. Sci. 95(1-2):27-37.

Ghasemi, M.V. and A. Ghorbani. 2014. Environmental and genetics factors affecting on semen quality in Iranian Holsteins bulls. Iranian J. App. Anim. Sci. 3(4):33-37.

Ghiasi, H. and M. Honarvar. 2016. Genetic and phenotypic trends of fertility traits in Iranian Holstein cows. Iranian J. App. Anim. Sci. 6(1):55-59.

Ghiasi, H., A. Pakdel, A. Nejati-Javaremi, O. Gonzalez-Recio, M.J. Carabano, R. Alenda and A. Sadeghi-Sefidmazgi. 2016. Estimation of economic value for fertility, stillbirth and milk production traits in 
Iranian Holstein dairy cows. Iranian J. App. Anim. Sci. 6(4):791-795.

Groen, F. and T. Steine. 1997. Economic values in dairy cattle breeding. with special reference to functional traits. Report of an EAAPworking group. J. Livest. Prod. Sci. 49(97):1-21.

Hardjosubroto, W. 1994. Aplikasi Pemuliabiakan Ternak di Lapangan. Grasindo, Jakarta.

Kumari, T., S. Pan and R.K. Coudhary. 2018. Effect of genetic group, season, their interaction, temperature, humidity and temperature-humidity index on maintenance behavior of stud bull. Iranian J. App. Anim. Sci. 8(2):207-213.

Kurnianto, E. 2012. Ilmu Pemuliaan Ternak. Undip Press, Semarang.

Nuryadi and S. Wahyuningsih. 2011. Penampilan reproduksi sapi Peranakan Ongole dan Peranakan Limousin di Kabupaten Malang. J. Ternak Tropika. 12(1):76-81.

Penitente-Filho, J.M., C. Guimaraes, B. Waddington, E.P. Costa, V.G. Leon, J.B. Siqueira, D.S. Okano, P.P. Maitan and J.D. Guimaraes. 2018. Relationship of testicular biometry with semen variables in breeding soundness evaluation of Nellore bulls. J. Anim. Reprod. Sci. 196:168-175.

Plaizier, J.C.B., G.J. King and J.C.M. Dekkers. 1997. Estimation of economic values of indices for reproductive performance in dairy herds using computer simulation. J. Dairy Sci. 80(11):2775-2783.

Purwantara, B., R.I. Arifiantini and M. Riyadhi. 2010. Sperm morphological assessment of Friesian Holstein bull semen collected from three artifician insemination centres in Indonesia. J. Indonesian Trop. Anim. Agric. 35(2):90-94.

Rotar, M.C., H. Grosu, M.A. Gras, R.S. Pelmus and C. Lazar. 2016. Comparative research on breeding value prediction for milk yield in cattle. Agriculture and Agricultural Science Procedia. 10:311-317.

Sadeghi, A.S., M.M. Shahrbabak, A.N. Javaremi, S.R.M. Ashtiani and P.R. Amer. 2012. Breeding objectives for Holsteins dairy cattle in Iran. J. Dairy Sci. 95(6):3406-3418.

Sholihin, M. and D. Ratmono. 2013. SEM-PLS Analisis dengan Warp-PLS 3.0. Andi, Yogyakarta.

Tiwari, R., G.K. Mishra, R.B. Singh, S.U. Rehman, K.S. Rathora, S.K. Saxena and M.U. Siddiqui. 2012. Seasonal variations in the quality and freezability of Red Sindhi bull semen. Indian J. Anim. Sci. 82(11):1344-1346.

Villa-Arcila, N.A., J. Sanchez, M.H. Ratto, J.C. Rodriguez, P.C. Duque, S. Sanchez-Arias and A. Ceballos. 2018. The association between subclinical mastitis around calving and reproductive performance in grazing dairy cows. J. Anim. Reprod. Sci. 185:109117.

Wilder, J.S. and L.D. Van Vleck. 1988. Relative economics values assigned to milk, fat test, and type in pricing of bull semen. J. Dairy Sci. 71(2):492-497.

Yang, D.H., N.T. Standley and Z.Z. Xu. 2018. Application of liquid semen technology under the seasonal dairy production system in New Zealand. J. Anim. Reprod. Sci. 194:2-10. 